\title{
Pengembangan Kewirausahaan Islam di UIN Sunan Ampel Surabaya Menuju Islamic Entrepreneurial University
}

\author{
Lilik Rahmawati \\ Dosen FEBI UINSA Surabaya | Lilik.Rahmawati@gmail.com
}

\begin{abstract}
Abstrak : Tujuan dari penelitian ini adalah untuk desain program kewirausahaan UIN Sunan Ampel dengan basis islamic entrepreneurial campus. penelitian ini terkategori library research dengan menggunakan pendekatan kualitatif. Adapun teknik pengumpulan data penelitian ini dengan studi dokumentasi. Analisis data yang dilakukan bersifat deskriptif-analisis. Desain Islamic Entrepreneurial University UIN Sunan Ampel dalam penelitian ini meliputi beberapa hal: pertama: penyelenggaraan kurikulum kewirausahaan terpadu; kedua: Peningkatan Sumber Daya Manusia; ketiga: Implementasi Entrepreneurship Center; keempat:Kerjasama dengan Dunia Usaha; Kelima: Membentuk Unit Usaha untuk mahasiswa; keenam:Kerjasama dengan Institusi Keuangan (perbankan/non perbankan); ketujuh: Penyelenggaraan Entrepreneurship Award.
\end{abstract}

Keywords : Kebijakan fiskal modern, sistem ekonomi Islam.

\section{Pendahuluan}

Upaya pemerintah untuk menggalakkan program kewirausahaan di perguruan tinggi cukup gencar. Pemerintah melalui Direktorat Jenderal Pendidikan Tinggi, Kementerian Pendidikan Nasional (Kemendiknas) telah meluncurkan Program Mahasiswa Wirausaha (PMW) yang telah dicanangkan sejak tahun 2009. ${ }^{1}$ Implementasi dari program ini berupa pemberian dana atau modal dalam bentuk subsidi untuk mahasiswa yang mempunyai usaha atau rencana usaha melalui seleksi proposal. Selain Kemendiknas, Kementerian Tenaga Kerja (Kemenakertrans) juga meluncurkan program Peningkatan Kompetensi Tenaga Kerja dan Produktivitas bagi Mahasiswa melalui pelatihan kewirausahaan yang dicanangkan sejak tahun 2010. Selain dua kementerian tersebut, Kementerian Koperasi dan Usaha Kecil Menengah (Kemenkop UKM) juga meluncurkan program pemberian modal untuk berwirausaha dengan agunan ijazah. ${ }^{2}$

Program-program kewirausahaan untuk mahasiswa diluncurkan oleh beberapa kementerian sebagai respon atas tingginya pengangguran alumnus perguruan tinggi. Data pengangguran terdidik di Indonesia berdasarkan data Badan Pusat Statistik menunjukkan, jumlah pengangguran sarjana pada Februari 2013 telah mencapai 360.000 orang, atau 5,04\% dari total

${ }^{1}$ Franova Herdiyanto, Program Mahasiswa Wirausaha, http: www.dikti.go.id, , diakses tanggal 28 Maret 2014.

${ }^{2}$ Heri Kuswara, Strategi Perguruan Tinggi Mewujudkan Entrepreneurial University, http: www.dikti.go.id, , diakses tanggal 28 Maret 2014. 
pengangguran yang mencapai 7,17 juta orang. ${ }^{3}$ Organization for Economic Cooperation Development (OECD) melaporkan lulusan perguruan tinggi Indonesia gagal mengimbangi keinginan pasar. Banyak perusahaan sulit menemukan orang yang bisa berpikir kritis dan mampu membuat transisi yang mulus dalam bekerja. Hal ini ditengarai karena lulusan perguruan tinggi biasanya tidak memiliki pengalaman kerja yang cukup. Kualitas lulusan yang tidak sesuai dengan kebutuhan dunia kerja itulah yang kemudian menyebabkan penyerapan lulusan sarjana di dunia kerja mengalami pelambatan. Pendidikan kewirausahaan akan semakin digalakkan di perguruan tinggi agar lulusan perguruan tinggi mampu mandiri. Pendidikan kewirausahaan di perguruan tinggi diharapkan bisa menyiapkan mahasiswa untuk berani mandiri, tidak lagi terfokus menjadi pencari kerja.

Generasi muda yang mempunyai jiwa entrepreneurial merupakan kekuatan besar dalam meningkatkan perekonomian negara. Peran entrepreneur dalam menentukan kemajuan suatu bangsa telah dibuktikan oleh beberapa negara maju seperti Amerika, Jepang, plus tetangga terdekat yaitu Singapura dan Malaysia. Betapa negara-negara tersebut, secara ekonomi sangat maju jauh meninggalkan Indonesia. Menurut sosiolog yaitu David McCleiland, sedikitnya dibutuhkan minimal 2 persen wirausaha dari populasi penduduknya, atau dibutuhkan sekitar 4,8 juta wirausaha di Indonesia saat ini. Begitupun menurutCiputra setidaknya dibutuhkan minimal 2 persen pengusaha untuk menjadikan bangsa ini bangkit dari keterpurukan. ${ }^{4}$

Bahkan salah satu perguruan tinggi di Amerika yaitu MIT (Massachusette Institute Technology) mengubah arah kebijakan perguruan tingginya dari High Learning Institute and Research University menjadi Entrepreneurial University ketika dalam kurun waktu tahun 1980-1996 Negara Amerika mengalami pengangguran terdidik yang semakin meluas dan kondisi ekonomi, sosial politik yang kurang stabil. Meskipun banyak pro kontra terhadap kebijakan tersebut namun selama kurun waktu tersebut MIT mampu membuktikan lahirnya 4 ribu perusahaan dari tangan alumni-alumninya dengan menyedot 1.1 juta tenaga kerja dan omset sebesar 232 miliar dolar pertahun. Sungguh prestasi yang luar biasa sehingga mengubah kondisi Negara Amerika menjadi negara super power. Kebijakan inilah yang selanjutnya ditiru dan diikuti oleh banyak perguruan tinggi sukses di dunia dan didukung oleh pemerintah negara setempat. ${ }^{5}$

Bagai gayung bersambut, upaya pemerintah untuk mengatasi pengangguran terdidik juga dilaksanakan di Indonesia dan diapresiasi positif

\footnotetext{
${ }^{3}$ Berita BPS Online, Data Pengangguran Sarjana, http:www.BPS.go.id

4 Heri Kuswara, Strategi Perguruan Tinggi Mewujudkan Entrepreneurial University, http: www.dikti.go.id, diakses tanggal 28 Maret 2014.

${ }^{5}$ Ibid
} 
oleh kalangan perguruan tinggi. Kini, wacana kewirausahaan sudah menjadi trending topic di perguruan tinggi baik umum maupun swasta. Perguruan tinggi berlomba-lomba menciptakan kampusnya menjadi entrepreneurial campus dengan mendirikan pusat kewirausahaan kampus. Sebut saja BSI Entrepreneurship Center (BEC) di Bina Sarana Informatika (BSI), Pusat Inkubator Bisnis ITB, Koperasi kesejahteraan Mahasiswa (KOKESMA) ITB, Community Business and Entrepreneurship Development (CBED) di STMB Telkom, Community Entrepreneur Program (CEP) UGM, Center for Entrepreneurship Development and Studies (CEDS) di UI, UKM Center di FEUI, Center for Entrepreneurship, Change, and Third Sector (CECT) di Universitas Tri Sakti, Binus Entrepreneurship Center (BEC) di Binus, Pusat Pembinaan Karier dan Kewirausahaan (PPKK) di UNAIR, Inkubator Bisnis Universitas Brawijaya (INBIS-UB) Malang, Pusat Studi Kewirausahaan dan Inkubasi Bisnis Universitas Hang Tuah (PSKI Malang), Pusat Pengembangan Kewirausahaan UII Yogyakarta, Pusat Studi Kewirausahaan Universitas Muhammadiyah Sidoarjo, serta Ciputra Surabaya yang telah mendeklarasikan menjadi kampus interpreneur di Indonesia dengan Ciputra Entrepreneurship School. ${ }^{6}$

Sebagaimana semangat kewirausahaan yang digalakkan oleh kampuskampus di Indonesia, iklim kewirausahaan di UINSA sudah mulai digalakkan sejak tahun 2011 yang dulu masih bernama IAIN Sunan Ampel. Pada tahun 2011 sampai tahun 2013, beberapa dosen diikutsertakan dalam workshop entrepreneurial, innovative teaching, and ventures di University of Sydney Australia. Selepas pengiriman beberapa dosen mengikuti workshop, selanjutnya kampus membentuk Lembaga Pengembangan kewirausahaan dan Bisnis Islam (LPKBI). LPKBI adalah sebuah lembaga nonstruktural kampus sebagai wadah penguatan dan pengembangan kewirausahaan Islam di kampus dengan tim kepengurusan meliputi dosen-dosen alumni program workshop di University of Sydney Australia utusan dari berbagai Fakultas. Beberapa program yang dicanangkan dan telah dijalankan oleh LPKBI, diantaranya adalah workshop kewirausahaan bagi mahasiswa dan dosen, pelatihan soft skill untuk mahasiswa seperti event organizer training, training membatik dan sablon, serta kegiatan Friday Market.

Selain LPKBI, segala hal yang berhubungan dengan bisnis dipusatkan di Pusat Bisnis. Pusat Bisnis berdiri tahun 2013 yang pada awalnya bernama Unit Pelaksana Teknis (UPT) Pusat Pengembangan Bisnis UIN Sunan Ampel. Pusat Bisnis merupakan lembaga berbasis bisnis milik kampus yang bergerak dalam berbagai bidang bisnis seperti penerbitan dan percetakan melalui Uinsa Press, property management, penjualan air mineral, penjualan handycraft dan

${ }^{6}$ Heri Kuswara, Strategi Perguruan Tinggi Mewujudkan Entrepreneurial University, http: www.dikti.go.id, , diakses tanggal 28 Maret 2014. 
souvenir khas kampus, dan layanan travel baik umroh maupun komersial, serta penyedia layanan hotel dan training centre melalui Green SA Inn.

Merujuk beberapa fakta di atas, maka penting untuk mengevaluasi program-program kewirausahaan yang telah dicanangkan oleh pimpinan universitas dan telah dilaksanakan selama lebih dari lima tahun ini. Selain itu, menangkap peluang implementasi model kewirausahaan dengan menonjolkan konsep keIslaman juga tidak kalah pentingnya di tengah kekosongan model kewirausahaan yang menfokus islamic entrepreneurial campus. Mengingat pusat-pusat kewirausahaan yang dikembangkan di beberapa perguruan tinggi negeri maupun swasta belum ada yang mengambil model islamic entrepreneurial campus. Oleh karena itu menjadi keniscayaan apabila UINSA Surabaya mengambil peran dengan mempunyai pusat kewirausahaan kampus dengan basis islamic entrepreneurial campus yang berbeda dengan kampus negeri dan swasta lainnya.

Urgensitas pengembangan kewirausahaan kampus dengan basis Islamic entrepreneurial campus di UINSA didasarkan atas beberapa hal pertama, program kewirausahaan yang dicanangkan oleh institusi dan telah dilaksanakan oleh sivitas akademika belum sesuai harapan. Kedua, UINSA mempunyai program studi keislaman. Adanya program studi keislaman seperti bahasa dan sastra arab, sejarah dan kebudayaan Islam, komunikasi dan penyiaran Islam, ilmu al-Quran dan tafsir, akhlaq dan tasawuf, ekonomi syariah dan lain sebagainya meniscayakan lahirnya produk-produk hasil karya mahasiswa maupun dosen yang khas sesuai karakter program studi.

Produk khas program studi ini layak untuk dikembangkan. Ketiga, UINSA merupakan Badan Layanan Umum (BLU). Dengan status BLU sudah selayaknya bisa memberikan ruang dan kesempatan yang luas untuk pengembangan bisnis pada aset bisnis yang dimiliki. Keempat, UINSA mempunyai Pusat Bisnis. Pusat Bisnis merupakan wadah kegiatan bisnis institut. Secara kelembagaan, melalui Pusat Bisnis UINSA bisa mengembangkan bisnis yang dimiliki. Selain itu dosen dan mahasiswa juga bisa melakukan kegiatan bisnisnya melalui pusat bisnis. Kelima, UINSA mempunyai Fakultas Ekonomi dan Bisnis Islam (FEBI) dan alumnus program workshop entrepreneurial, innovative teaching, and ventures di University of Sydney Australia. Dengan demikian sumber daya manusia baik dari kalangan dosen dan mahasiswa yang concern di bidang kewirausahaan Islam cukup banyak.

Di samping itu, pengembangan kewirausahaan dengan basis islamic entrepreneurial campus di kampus Islam termasuk di UINSA cukup prospektif. Hal ini dapat dilihat dari fakta penduduk Indonesia yang 85\% mayoritas muslim. Implikasinya, kebutuhan konsumen muslim terhadap produk-produk dengan atribut keislaman juga cukup banyak. Di sisi lain, kampus Islam mempunyai tokoh sentral entrepreneur yang sudah diakui oleh semua 
kalangan yaitu Nabi Muhammad saw. Karakter dan jiwa entrepreneurial Nabi Muhammad saw yang melakukan kegiatan bisnis dengan menerapkan etika bisnis Islam, penuh kejujuran, kegigihan, kreatif dan inovatif, menjadi dasar dalam perumusan kurikulum kewirausahaan dengan basis islamic entrepreneurial campus

Berdasarkan latar belakang di atas, maka penelitian ini dipandang perlu untuk merekonstruksi program kewirausahaan yang telah ada melalui pengembangan desain program kewirausahaan dengan basis islamic entrepreneurial campus

\section{Rumusan Masalah}

Berdasarkan latar belakang, maka rumusan masalah pada penelitian ini adalah: Bagaimana desain program kewirausahaan UIN Sunan Ampel dengan basis islamic entrepreneurial campus?

\section{Tujuan Penelitian}

Penelitian ini bertujuan untuk merancang desain program kewirausahaan dengan basis islamic entrepreneurial campus.

\section{Manfaat Penelitian}

Penelitian ini diharapkan dapat bermanfaat secara teoritis maupun praktis.

a. Secara teoritis, penelitian ini diharapkan dapat menambah dan melengkapi kajian-kajian ekonomi Islam khususnya kewirausahaan Islam

b. Secara praktis, penelitian ini juga dapat bermanfaat kepada beberapa pihak yaitu

Pertama, bagi mahasiswa dapat menambah wawasan kewirausahaan Islam dan terbentuk jiwa enterpreneur yang senantiasa berpikir, bersikap, dan bertindak kreatif dan inovatif

Kedua, bagi pimpinan perguruan tinggi sebagai sumbangan informasi untuk menentukan kebijakan pengembangan arah program kewirausahaan di kampus terutama bagi UPT Pusat Bisnis UIN Sunan Ampel Surabaya.

Ketiga, bagi Lembaga Penjamin Mutu (LPM) sebagai sumbangan informasi dalam perumusan standar mutu pelaksanaan pendidikan di UINSA

Keempat, bagi penyelenggara pendidikan kewirausahaan di tingkat Prodi maupun Fakultas sebagai bahan pertimbangan dalam penyusunan kurikulum kewirausahaan

Kelima, bagi peneliti lain untuk digunakan sebagai bahan referensi melanjutkan maupun mengembangkan penelitian sejenis. 


\section{Penelitian Terdahulu}

Kajian terhadap penelitian terdahulu dimaksudkan untuk mengetahui posisi penelitian. Artinya posisi yang akan dilakukan merupakan penelitian yang baru atau penelitian pengembangan sehingga tidak dikategorikan duplicated research. Ada beberapa penelitian sejenis yang telah dilakukan peneliti terdahulu. Berikut ini akan dipaparkan penelitian terdahulu berikut letak perbedaan serta persamaan penelitian ini dengan penelitian terdahulu

a. Implementasi Program Kursus Kewirausahaan Kota di Pusat Kegiatan Belajar Masyarakat (PKBM) Wijaya Kusuma dalam Peningkatan Kesejahteraan Keluarga. ${ }^{7}$

Penelitian ini adalah skripsi Gesta Septi Nugraheni Jurusan Pendidikan Luar Sekolah Fakultas Ilmu Pendidikan Universitas Negeri Yogyakarta tahun 2012.

Skripsi ini ingin mengetahui imlementasi program kursus kewirausahaan dalam kaitannya untuk meningkatkan kesejahteraan keluarga. Pendekatan penelitiannya kualitatif dengan metode pengumpulan data dengan wawancara, observasi, dan dokumentasi.

b. Politik Ekonomi Generasi Muda Implementasi Kebijakan Kewirausahaan Nasional di Jawa Timur. ${ }^{8}$

Penelitian Adhimas Ramadhan FISIP Unair yang diterbitkan oleh Jurnal Politik Muda. ISSN 2302-8068 Vol 2. No 1 Terbit Januari 2013. Jurnal ini membahas implementasi kebijakan kewirausahaan Nasional di Jawa Timur dengan menggunakan analisis kebijakan teori Grindle

c. Pembelajaran Kewirausahaan di PTAIN di Jawa Timur: Perspektif Strategi Pembelajaran. ${ }^{9}$

Penelitian ini ditulis oleh Salim Al Idrus, Fakultas Ekonomi Universitas Islam Negeri Maulana Malik Ibrahim Malang. Penelitian ini adalah penelitian kualitatif dengan menggunakan pendekatan studi kasus. Hasil penelitian menjelaskan bahwa Pembelajaran mata kuliah Kewirausahaan di PTAIN Jawa Timur menerapkan model konvensional/tradisional.

\footnotetext{
${ }^{7}$ http:www.eprints.uny.ac.id/9537/4/cover\%20-\%2008102244002.pdf. Diakses tanggal 28 Maret 2014

${ }^{8}$ http:www.ejournal.uinmalang.ac.id/index.php/ekonomi/article/viewFile/.../pdf. Diakses tanggal 28 Maret 2014

${ }^{9}$ http://journal.unair.ac.id/article_4624_media80_category80.html. Diakses tanggal 28 Maret 2014.

${ }^{10}$ http:www.library.walisongo.ac.id/digilib/download.php?id=19905 . Diakses tanggal 28 Maret 2014
} 
d. Implementasi Model Pendidikan Pesantren Berbasis Akhlaq Plus Wirausaha di Pesantren Daarut Tauhid Bandung. ${ }^{10}$

Penelitian ini adalah skripsi yang ditulis oleh Nur Chahyadi, Fakultas Tarbiyah IAIN Walisongo Semarang 2009.

Skripsi ini membahas tiga tahapan pendidikan yang diterapkan oleh pesantren Daarut Tauhid dalam pengembangan pendidikan pesantren berbasis akhlaq dan wirausaha.

e. Islam dan Mental Kewirausahaan: Studi tentang Konsep dan Pendidikannya. ${ }^{11}$

Penelitian ini ditulis oleh Subur, mahasiswa program pascasarjana STAIN Purwokerto. Isi penelitian ini menegaskan pentingnya praktisi pendidikan memberikan ruang yang kondusif pada masyarakat agar jiwa/mental entrepreneurship dapat tumbuh dan berkembang menjadi bagian penting dalam hidupnya dan dapat menjadi pilihan dalam beraktivitas. Mengingat karakteristik dalam entrepreneurship adalah bekerja dengan sungguh-sungguh, maka di samping melakukan upaya yang bersifat kerja nyata juga tidak kalah penting, menurut logika orang beragama untuk memperhatikan hal yang bersifat non teknis; meningkatkan kualitas spiritual adalah upaya yang sangat penting dilakukan

f. Pengaruh Pembelajaran Kewirausahaan terhadap Minat Berwirausaha Siswa kelas XI Pada Jurusan Akuntansi Di SMK Negeri 1 Bandung. ${ }^{12}$

Penelitian ini merupakan skripsi yang dilakukan Nur Ayani Fathonah. Penelitian dilakukan pada kelas XI Jurusan Akuntansi di SMK Negeri 1 Bandung. Metode yang digunakan dalam penelitian ini adalah deskriptif verifikatif. Hasil penelitian membuktikan adanya Pengaruh Pembelajaran Materi Kewirausahaan terhadap Minat Berwirausaha Siswa. Teknik pengolahan data menggunakan SPSS.

Dari penelusuran penelitian terdahulu, maka pada umumnya penelitian-penelitian terdahulu banyak membahas implementasi kewirausahaan yang umum bukan spesifik Islam. Selain itu, jika dikaitkan dengan implementasi kewirausahaan di ranah pendidikan, maka secara umum penelitian terdahulu hanya membahas terapan metode pembelajarannya saja sebagaimana penelitian Salim dan Chahyadi bukan membahas programprogram kewirausahaan yang diterapkan di kampus seperti halnya fokus masalah pada penelitian yang akan dilaksanakan ini. Dengan demikian maka

${ }^{11}$ Subur, "Islam dan Mental Kewirausahaan: Studi tentang Konsep dan Pendidikannya" Jurnal Pemikiran Alternatif Pendidikan (STAIN Purwokerto: Insania, Vol. 12 No. 3)

12 Nur Ayani Fathonah, "Pengaruh Pembelajaran Kewirausahaan terhadap Minat Berwirausaha Siswa kelas XI Pada Jurusan Akuntansi Di SMK Negeri 1 Bandung", Skripsi ( Unesa Surabaya) 
penelitian ini yang akan dilaksanakan ini bukan duplikasi penelitian terdahulu atau duplicated research.

\section{Kajian Teoritik}

Selain penelusuran penelitian terdahulu, kajian-kajian teoritis terkait topik penelitian yang dibahas oleh para ahli sangat penting untuk dikaji sebagai dasar pijakan teoritis atas penelitian yang dilaksanakan. Dalam penelitian ini, kajian teori difokuskan kepada konsep-konsep kewirausahaan, terapan kewirausahaan di perguruan tinggi, dan kewirausahaan perspektif Islam. Konsep kewirausahaan telah banyak dikemukakan oleh beberapa ahli diantaranya adalah Hisrich-Peter, John Kao, Winarto, dan Suryana. Kewirausahaan Menurut Hisrich-Peter (1995) sebagaimana dikutip dalam (Alma, 2009) adalah diciptakannya sesuatu yang baru atau inovasi dari yang sudah ada dengan waktu dan kegiatan yang disertai oleh modal dan risiko yang nantinya akan menghasilkan balas jasa, kepuasan, dan rasa mandiri. ${ }^{13}$ Sedangkan Kao (1991) yang dikutip oleh Sudjana (2004) menyebutkan bahwa kewirausahaan adalah sikap dan perilaku wirausaha. Wirausaha ialah orang yang inovatif, antisipatif, inisiatif, pengambil risiko dan berorientasi laba. Ini ber arti kewirausahaan merupakan sikap dan perilaku orang yang inovatif, antisipatif, inisiatif, pengambil risiko dan berorientasi laba. Sedangkan Winarto menyebutkan bahwa entrepreneurship (kewirausahaan) adalah suatu proses melakukan sesuatu yang baru dan berbeda dengan tujuan menciptakan kemakmuran bagi individu dan memberi nilai tambah pada masyarakat.

Terkait terapan kewirausahaan di lembaga pendidikan, beberapa ahli telah membahasnya. Sebut saja Idrus (1999) yang mengkaji masalah strategi pengembangan kewirausahaan dan peranan perguruan tinggi dimana perguruan tinggi yang strategis perlu diaktifkan untuk mendorong percepatan perluasan kesempatan kerja melalui pengembangan pelaku-pelaku ekonomi baru (entrepreneur) yang terampil dan mempunyai teknologi maju, berusia muda yang produktif, kreatif dan berdaya saing. ${ }^{14}$ Soemanto (1984) mengkaji tentang pendidikan dan persiapan manusia wiraswasta di lingkungan sekolah dan masyarakat di mana banyak orang yang ingin hidup maju dan berhasil dengan menumpukan sepenuhnya harapan mereka kepada sekolah-sekolah, baik di kalangan orang tua maupun di kalangan generasi muda yang mempunyai harapan besar agar melalui sekolah akan diperoleh nasib yang lebih baik, kemajuan dan kesuksesan dalam hdup. Di samping itu banyak pula

${ }^{13}$ Buchari, Alma, Kewirausahaan, (Bandung: Alfabeta, 2009), 12

${ }^{14}$ M. Syafei, Idrus, Strategi Pengetahuan Kewirausahaan dan Peranan Perguruan Tinggi Dalam Rangka Membangun Keunggulan Bersaing Bangsa Indonesia pada Milenium Ketiga, (Malang: PPS UMM Malang, 1999), 34 
orang yang ingin hidup maju dan berhasil dengan menempuh pengalamanpengalaman praktis di lingkungan masyarakat. ${ }^{15}$ Lupiyoadi dan Wacik (1998) mengkaji masalah wawasan kewirausahaan dalam membangun kecenderungan mental, khususnya di kalangan perguruan tinggi, yaitu menyadarkan pada mahasiswa bahwa kewirausahaan bisa dipelajari dengan mengajak belajar berproses, mengajak menyelami karakter dan motivasi wirausaha, membuka cakrawala fenomena bisnis dan bagaimana berhitung untuk menjadi wirausaha, mengajak menimbang dan memilih berbagai bentuk usaha dan bagaimana memulainya. ${ }^{16}$

Terkait konsep kewirausahaan Islam, Harahap (2010) mengkaji Etika Bisnis dalam Perspektif Islam. Di antara etika bisnis yang harus dipegang teguh oleh seorang wirausaha di antaranya jujur, amanah, dan menghindari riba. ${ }^{17}$ Senada dengan Harahap adalah Mustaq (2006) yang mengkaji mengenai Etika Bisnis Dalam Islam. ${ }^{18}$ Penulis lain adalah Sahid (2013) yang membahas wirausaha berbasis Islam dan kebudayaan. Dengan pengalamannya sebagai pengusaha, Sahid memaparkan pengalamannya menjalankan usahanya dan bagaimana prinsip-prinsip kewirausahaan Islam menjadi dasar dalam menjalankan suatu bisnis. ${ }^{19}$ Natsir (1999) secara khusus mengkaji masalah pemahaman etika kerja (Islam) terhadap tingkah laku kewirausahaan dimana dalam proses pembangunan para ahli ekonomi mengakui akan pentingnya peranan tingkah laku kewirausahaan dalam memajukan perkembangan ekonomi suatu bangsa. Tinggi rendahnya tingkah laku kewirausahaan tersebut berkaitan dengan berbagai faktor. Salah satu faktor utama adalah dasar keyakinan, pandangan hidup atau agama yang menjadi daya pendorong tingkah laku, selain itu juga dipengaruhi oleh berbagai faktor yang berkaitan secara kompleks baik faktor budaya, agama maupun faktor struktur sosial. ${ }^{20}$

\section{Metode Penelitian}

Sesuai dengan tujuan yang ingin diraih, penelitian ini terkategori library research dengan menggunakan pendekatan kualitatif. Adapun teknik pengumpulan data penelitian ini dengan studi dokumentasi. Teknik dokumentasi merupakan penelaahan terhadap referensi berupa dokumen-

\footnotetext{
${ }^{15}$ Wasty, Soemanto, Pendidikan Wiraswasta, (Jakarta: Bumi Aksara, 1994), 25

${ }^{16}$ Rambat Lupiyadi dan Jero Wacik, Wawasan Kewirausahaan, Cara Mudah Menjadi Wirausaha, (Jakarta: LPFE Universitas Indonesia, 1998)

17 Sofyan Safri Harahap, Etika Bisnis dalam Perspektif Islam.(Jakarta:Salemba Empat,2010), 14-15

${ }^{18}$ Ahmad Mustaq, Etika Bisnis Dalam Islam. (Jakarta:Pustaka Al-Kautsar,2006)10-12

19 Sukamdani Sahid Gitosardjono , Wirausaha Berbasis Islam dan Kebudayaan, (Jakarta: Bisnis Indonesia, 2013)

${ }^{20}$ Nanat Fatah, Natsir, Etos Kerja Kewirausahaan Muslim, (Bandung: Gunung Jati Press, 1999)
} 
dokumen yang berhubungan dengan fokus permasalahan. Dokumen dapat peneliti peroleh dari studi kepustakaan maupun data dari penelusuran melalui internet yang berkaitan tentang Pogram-program kewirausahaan yang mendukung penerapan Islamic Entrepreneurial University di UIN Sunan Ampel

Analisis data yang dilakukan bersifat deskriptif-analisis. Karena bersifat deskriptif-analisis peneliti ingin menjelaskan secara jelas dan luas terhadap permasalahan yang diteliti. Analisis data yang dilakukan bersifat iteratif (berkelanjutan) yang dilakukan selama dan setelah kegiatan pengumpulan data berlangsung. Analisis selama pengumpulan data dimaksudkan agar peneliti dapat langsung melakukan analisis sedini mungkin data yang dibutuhkan dan sekaligus dapat melakukan pembenahan jika terdapat kekurangan data. Sedangkan analisis setelah kegiatan pengumpulan data dimaksudkan untuk mengolah lebih lanjut data yang terkumpul sesuai temuan fokus penelitian. ${ }^{21}$

\section{A. Pembahasan}

Perguruan tinggi sebagai salah satu mediator dan fasilitator terdepan dalam membangun generasi muda bangsa mempunyai kewajiban dalam mengajarkan, mendidik, melatih dan memotivasi mahasiswanya sehingga menjadi generasi cerdas yang mandiri, kreatif, inovatif dan mampu menciptakan berbagai peluang pekerjaan (usaha). Untuk itu sebuah keharusan bagi setiap perguruan tinggi segera merubah arah kebijakan perguruan tingginya darihigh Learning university and Research University menjadi Entrepreneurial University atau menyeimbangkan kedua arah kebijakan tersebut sehingga arah kebijakan keduanya tercapai baik yang bersifat high Learning university and Research University maupun yang bersifat Entrepreneurial University.

Sebagaimana penjelasan Asha Gupta secara kongkrit entrepreneurial universitry memiliki makna, pertama perguruan tinggi dapat menjadi lembaga kewirausahaan dan organisasi yang dapat memanfaatkan secara optimum efisien sumber daya (khususnya SDM) yang dimiliki. Kedua, para mahasiswa, staf pengajar dan fakultas terintegrasi dengan lembaga bisnis, industri, dan komunitas (stakeholders) melalui inovasi dan pengenalan ilmu pengetahuan dan kerjasama dengan industri.

Makna pertama dapat diimplementasikan secara nyata dalam bentuk pemanfaatan peluang dengan memproduksi barang dan jasa dengan menggunakan secara optimal dan efisien semua sumber daya, seperti uang, bahan baku, teknologi, mesin, keterampilan, dan tenaga kerja agar menghasilkan produk yang berdaya saing dan menguntungkan. Makna kedua

\footnotetext{
${ }^{21}$ Imam Suprayogo dan Tobroni, Metode Penelitian Sosial Agama,( Bandung:Remaja Rosda Karya), 192
} 
dapat diimplementasikan secara nyata dalam bentuk komitmen seluruh anggota perguruan tinggi, seperti mahasiswa, staf dosen dan karyawan, manajemen, terhadap semangat, dorongan, dukungan dalam mewujudkan perguruan tinggi sebagai pusat kewirausahaan. ${ }^{22}$ Dengan demikian penciptaan iklim Islamic Entrepreneurial University di UIN Sunan Ampel mengandung makna bahwa dalam setiap program kewirausahaan yang digagas senantiasa dilingkupi dengan ruh keislaman dalam wujud etika bisnis Islam oleh seluruh sivitas akademika.

Untuk melahirkan entrepreneur-entrepreneur muda sukses diperlukan kesungguhan dan keseriusan dari perguruan tinggi dalam mengemban misi Islamic entrepreneurial university. Beberapa hal yang harus dimiliki perguruan tinggi untuk mendukung misi Islamic entrepreneurial university adalah:

1. Kurikulum kewirausahaan terpadu

2. Peningkatan Sumber Daya Manusia

3. Entrepreneurship Center

4. Kerjasama dengan Dunia Usaha.

5. Membentuk Unit Usaha untuk mahasiswa

6. Kerjasama dengan Institusi Keuangan (perbankan/non perbankan).

7. Entrepreneurship Award

Detail penjelasan dipaparkan di tabel 1 berikut

22 Gupta, V., I.C. MacMillan, and G. Surie. 2004. "Entrepreneurial leadership: Developing andmeasuring a cross-cultural construct." Journal of Business Venturing 19: 241-60 
Pengembangan Kewirausahaan Islam di UIN

Tabel 1: Desain program kewirausahaan Islam berbasis Islamic Entrepreneurial University di UIN Sunan Ampel

\begin{tabular}{|c|c|c|c|}
\hline Program & & Bentuk & Implementasi \\
\hline $\begin{array}{l}\text { 1. Kurikulum } \\
\text { Terpadu }\end{array}$ & & Integrasi Keilmuan & $\begin{array}{l}\text { Integrasi dimulai pada saat } \\
\text { - Pembuatan perangkat pembelajaran seperti } \\
\begin{array}{l}\text { silabus, satuan acara pengajaran (SAP), Slide } \\
\text { Presentasi, modul teori, modul } \\
\text { praktikum/praktek, pembuatan buku } \\
\text { panduan. } \\
\text { Proses pembelajaran sudah menerapkan } \\
\text { integrasi keilmuan }\end{array}\end{array}$ \\
\hline $\begin{array}{l}\text { 2. Peningkatan } \\
\text { Sumber } \\
\text { Manusia }\end{array}$ & Daya & $\begin{array}{l}\text { Pendidikan dan Pelatihan } \\
\text { bagi Dosen dan Staf }\end{array}$ & $\begin{array}{l}\text { - Program Short course entrepreneurship (program } \\
\text { pelatihan kewirausahaan untuk dosen), } \\
\text { - Program seminar/ workshop/lokakarya } \\
\text { entrepreneurship. } \\
\text { - program pemagangan dosen di dunia usaha, } \\
\text { - program sarasehan dengan mitra usaha/dunia } \\
\text { usaha }\end{array}$ \\
\hline
\end{tabular}

89 | Volume 5, No. 1, Des 2018 


\begin{tabular}{|c|c|c|c|}
\hline & & & $\begin{array}{l}\text { - program pembinaan/ pendampingan dosen } \\
\text { baru. }\end{array}$ \\
\hline & $\begin{array}{l}\text { Entrepreneurship } \\
\text { Center }\end{array}$ & $\begin{array}{l}\text { Pusat Kewirausahaan } \\
\text { (entrepreneurship centre) } \\
\text { di tingkat perguruan } \\
\text { tinggi atau di tingkat } \\
\text { mahasiswa }\end{array}$ & $\begin{array}{l}\text { - Pusat Kewirausahaan (entrepreneurship centre) } \\
\text { di tingkat perguruan tinggi dan incubator } \\
\text { bisnis } \\
\text { - UKM (Unit Kegiatan Mahasiswa) } \\
\text { Kewirausahaan dan atau Komunitas Bisnis } \\
\text { Mahasiswa di tingkat mahasiswa. }\end{array}$ \\
\hline & $\begin{array}{l}\text { Kerjasama dengan } \\
\text { Dunia Usaha. }\end{array}$ & $\begin{array}{l}\sim \text { Kerjasama dalam } \\
\text { Pendidikan Pelatihan } \\
\text { dan } \sim \text { Membangun bisnis } \\
\text { untuk kemanfaatan } \\
\text { bersama (profit oriented }\end{array}$ & $\begin{array}{l}\text { - Pelaksanaan kunjungan edukasi, magang, atau } \\
\text { tempat skripsi. } \\
\text { - Implementasi dalam bidang pemenuhan } \\
\text { kebutuhan barang dan jasa seperti katering, } \\
\text { transportasi dan ticketing, layanan wifi dll }\end{array}$ \\
\hline & $\begin{array}{l}\text { Membentuk Unit } \\
\text { Usaha untuk } \\
\text { mahasiswa }\end{array}$ & $\begin{array}{l}\text { Koperasi maupun matket } \\
\text { place }\end{array}$ & $\begin{array}{l}\text { Koperasi mahasiswa atau stand khusus } \\
\text { untuk media berwirausaha dengan sistem } \\
\text { sewa }\end{array}$ \\
\hline & $\begin{array}{l}\text { Kerjasama dengan } \\
\text { Institusi Keuangan } \\
\text { (perbankan/non }\end{array}$ & $\begin{array}{l}\sim \text { Kerjasama } \text { dalam } \\
\text { Pendidikan Pelatihan } \\
\text { dan } \sim \text { Membangun bisnis }\end{array}$ & $\begin{array}{l}\text { - Pelaksanaan kunjungan edukasi, magang, atau } \\
\text { tempat skripsi. } \\
\text { - Penempatan kantor kas atau ATM dan }\end{array}$ \\
\hline
\end{tabular}

90 | OECONOMICUS Journal Of Economics 
Pengembangan Kewirausahaan Islam di UIN

\begin{tabular}{|l|l|l|}
\hline perbankan). & $\begin{array}{l}\text { untuk kemanfatan } \\
\text { bersama (profit oriented) }\end{array}$ & pemberian beasiswa \\
\hline $\begin{array}{l}\text { 7. Entrepreneurship } \\
\text { Award }\end{array}$ & $\begin{array}{l}\text { Kompetisi internal dan } \\
\text { eksternal }\end{array}$ & $\begin{array}{l}\text { Kompetisi internal misalnya kompetisi } \\
\text { business plan, kompetisi ide bisnis,pemilihan } \\
\text { mahasiswa entrepreneur, pemilihan alumni } \\
\text { entrepreneur, dan lain-lain. }\end{array}$ \\
& $\begin{array}{l}\text { Kompetisi dari eksternal dapat dilakukan } \\
\text { dengan mengikutsertakan mahasiswa dalam } \\
\text { berbagai kompetisi kewirausahaan yang } \\
\text { dilaksanakan oleh berbagai pihak seperti, } \\
\end{array}$ & $\begin{array}{l}\text { BankMandiri (Wirausaha Muda Mandiri- } \\
\text { WMM danProgram Mahasiswa Wirausaha- }\end{array}$ \\
& PMW), BankIndonesia (Penciptaan Wirausaha \\
& Baru). Dalam bentuk lain bisa berupa Festival \\
& Wirausaha Mahasiswa. \\
\hline
\end{tabular}

91 | Volume 5, No. 1, Des 2018 
Berdasarkan tabel 1 di atas banyak sekali program yang bisa diimplementasikan dalam rangka Desain program kewirausahaan Islam berbasis Islamic Entrepreneurial University di UIN Sunan Ampel

Olrena itu diperlukan upaya yang sungguh yang diawali dengan kemauan bersama antara pimpinan internal di level Universitas maupun Fakultas serta Unit-Unit Bisnis dalam leading sector Pusat Bisnis untuk menerapkan desain sehingga bisa bermanfaat nyata.

\section{B. Penutup}

Desain Islamic Entrepreneurial University UIN Sunan Ampel dalam penelitian ini meliputi beberapa hal:

1. Penyelenggaraan kurikulum kewirausahaan terpadu

2. Peningkatan Sumber Daya Manusia

3. Implementasi Entrepreneurship Center

4. Kerjasama dengan Dunia Usaha.

5. Membentuk Unit Usaha untuk mahasiswa

6. Kerjasama dengan Institusi Keuangan (perbankan/non perbankan).

7. Penyelenggaraan Entrepreneurship Award

Menilik manfaatnya bagi terciptanya iklim kewirausahaan di kalangan sivitas akademika dan peningkatan profit income bagi universitas, maka implementasi substansi Islamic Entrepreneurial University menjadi sebuah keniscayaan. Namun kembali lagi kepada penentu kebijakan universitas, apakah konsep Islamic Entrepreneurial University ingin diaplikasikan atau tidak, sehingga implementasi konsep ini bergantung kepada kesatuan pandang para pimpinan universitas. Dengan demikian atas hasil penelitian ini, peneliti merekomendasikan hal-hal berikut:

Pertama, pihak LPPM memberikan masukan kepada pimpinan universitas; kedua, pimpinan universitas mengkaji konsep Islamic Entrepreneurial University; ketiga, pimpinan universitas merumuskan langkahlangkah awal menuju penerapan Islamic Entrepreneurial University 


\section{DAFTAR PUSTAKA}

Bungin, Burhan, Metodologi Penelitian Kualitatif. Jakarta: PT Raja. Grapindo Persada, 2007

Company Profile Pusat Pengembangan Bisnis UINSA.

Fatch, Muhammad, Inkubator Bisnis Universitas Brawijaya, Lembaga Pengabdian Masyarakat, (Malang: Universitas Brawijaya, 2000

Hamdan, Universitas Serang Raya, Jurnal Bisnis dan Kewirausahaan, Mei 2016 Vol. 15 ISSN 1412-565 X

Hasbullah, Rokhani dkk, Jurnal Ilmu Pertanian Indonesia (JIPI), April 2015 Vol. 20 (1): 59-65. ISSN 0853 - 4217, IPB Bogor

Moleong, Lexy, Metodologi Penelitian Kualitatif (Edisi Revisi),(Jakarta: Rosda,2000)

Nur Syam, "Sudah Satker BLU, Mind Set Masih Satker Traditional", dalam https://kemenag.go.id. Diakses pada tanggal 15 Oktober 2017.

Setyobudi, Inkubator Bisnios di Perguruan Tinggi, (Malang:Universitas Brawijaya

Slamet, 2014, Laporan Penelitian, Fakultas Ekonomi, UIN Maulana Malik Ibrahim Malang

Suprayogo, Imam dan Tobroni, Metode Penelitian Sosial Agama,( Bandung:Remaja Rosda Karya)

Sutopo, Metode Penelitian Kualitatif. (Surakarta: UNS Press.1996 ) 138

Suwandi, 2008. Laporan Hasil Penelitian Balitbang Depdiknas Jakarta.

Wibawa, Sutrisna, 2012, Laporan Penelitian, Fakultas Ekonomi, Universitas Negeri Yogyakarta.

http://www.blu.djpbn.kemenkeu.go.id. Diakses pada tanggal 15 Oktober 2017 